\title{
SCIENCE, NATIONAL AND INTERNATIONAL, AND THE BASIS OF CO-OPERATION*
}

\author{
By Prof, A. V. Hill, O.B.E., F.R.S., M.P.
}

$\mathrm{O}_{\mathrm{ras}}^{\mathrm{s}}$ $\mathrm{NE}$ of the great tasks lying before scientific people after the present War will be to rebuild, and to rebuild on a firmer and better foundation, the international scientific organizations which have come into being in the last seventy years, particularly during the present century. The earliest of these was the International Bureau of Weights and Measures, established in 1873. An International Geodetic Association followed, and in 1903 an International Seismological Association on the same lines. Arising from the initiative in 1898 of the Academies of Munich and Vienna, together with the Royal Societies of Göttingen and Leipzig, which had all been in the habit of meeting annually, the Royal Society of London undertook to approach a number of foreign academies with a view to the formation of an international association of academies. As an independent institution, not subject to State control as were so many of the academies, the Royal Society was in a very favourable position for opening such negotiations. As a result the International Association of Academies was formed, which held five meetings in all, the sixth at St. Petersburg being cancelled owing to the outbreak of war in 1914. It never met again.

These meetings were not limited to natural science, many of the academies being concerned both with the scientific and the humanistic side of learning. It is interesting to interpolate that as one result of this movement, and in order to represent Great Britain on the literary, philosophical and historical sides, the British Academy was formed and incorporated by Royal Charter in 1902 .

Just before the end of the last war, in 1918, representatives of the academies of all the allied countries met in London, and later in Paris, to discuss the formation of a new international scientific organization. In July 1919, the first General Assembly of the International Research Council, as it was to be called, met in Brussels. Representatives of the Central Powers were not invited, and a misunderstanding which then arose was made an excuse for declining an invitation which was sent to each of them a few years later. This unfortunate state of affairs persisted. German professors who feel themselves insulted are difficult people to appease, and indeed the fault was not all on their side. International Unions for As-

* From an address given at the annual general meeting of the Parliamentary and Scientific Committee on January 28. tronomy, Geodesy and Geophysics, Chemistry and Mathematics (this last no longer in existence) were formed; and at the next General Assembly in 1922, for Physics, Scientific Radio, Geography and Biology. Some of these Unions have functioned well and have held important international congresses and done important work; others have done little. The ones that have worked best, for example, Scientific Radio, are those which had a more practical international task to fulfil.

These Unions always had an official or semiofficial flavour: official delegates, official hospitality, official finance, official business, have tended to put independent science into a somewhat subordinate position. Physiologists have held international congresses for fifty years, and great value these have had, as we who have taken part in them know : but physiologists have always insisted that they came as independent men of science, to meet, to hear and to discuss things with their colleagues; not as representatives of some State institution or interest. Other scientific groups have held similar informal congresses based on the same idea. There is grave danger, as was found by the Physiological Congress meeting in Italy in 1932, and in the Soviet Union in 1935, of a congress being used as an opportunity for political propaganda; in 1938 this was altogether avoided by the tact and understanding of Swiss colleagues, as it had been avoided at meetings prior to 1932. Political considerations are hard enough to avoid anyhow, but they are much worse if a congress is not genuinely independent.

In Great Britain and in the United States, the strength and the high position of the independent scientific societies make it easy for them to take charge of the proceedings of a congress, or of an inquiry of international importance, without danger of State control-either in appearance or reality. But this is not so easy-indeed it has been impossible in recent years-in many countries. In order to preserve the integrity of science in our own country, it is very important that those strong independent scientific bodies should be maintained; and for the sake of international scientific relations it is desirable that in other countries also, so far as we can influence them, the domination of the State over science should be tempered by public appreciation of the part played by independent scientific agencies and institutions.

In some form or other, not one may hope 
exactly in their present form, these international unions must be started up again some day. This time, at any rate, we shall not be prevented from following our better judgment by the intransigence of French colleagues; though it may be hard enough for us this time to take a detached view. My own feeling is that in this matter we should rely, so far as possible, upon the help and advice of our American scientific friends. Their views about science, for its own sake and in relation to the State, are much the same as ours, and they (at present at least) are further from the battle. I know they would regard it as a sacred trust of friendship to bear a large part of the burden of starting off again the international co-operation in scientific endeavour which was so unhappily ended by the events of the last years. There is a high idealism in the United States about international co-operation in the field of science and learning, and a very great regard for British science and British scientific men. If the War goes ultimately as we expect, in the downfall of dictatorship and tyranny, it will be our job to start off again, on broader and better lines, the complex system of international scientific co-operation ; and in starting it off $\mathrm{I}$ am sure that we shall be able to call for the help and co-operation, without stint or limit, of our scientific friends in the United States.

I have spoken several times of the necessity of guarding the independence, the spiritual integrity of science. In many countries to-day science is wholly subservient to the State; its soul is not its own. I do not deny for a moment the importance, indeed the necessity, of scientific organizations within the framework of Government, or of liberal support by the State of scientific research. One can only welcome such recognition by the public of the importance of scientific knowledge and scientific discovery - and ask for more. There are several things, however, which one may fear. First, the condition of stagnation and complacency which tends to develop in any scientific department or establishment which is cut off from outside criticism or ideas ; we have far too many examples of this already, and if we are not careful they will multiply. Secondly, the danger that science will be planned by administrators in offices instead of by young men with their sleeves rolled up in laboratories or workshops. Thirdly, the disadvantage of separating teaching from research, to the great loss of the next generation, who may miss the inspiration of seeing discovery going on in the places where they are taught. Fourthly, a decrease in the influence and prestige of those independent scientific bodies which play so large a part in the social and intellectual activities of the scientific community and provide the cross-connexions between groups which might otherwise be isolated.
Fifthly, the danger that he who pays the piper may call the tune, and that research may be required to be devoted primarily to objects which the politician, or the Civil Servant, regard for the moment as of national importance; or even-as in Germany and the Soviet Union-to bolstering up theories which the official philosophy of the State prescribes.

To avoid all these troubles, the independence and integrity of science must be carefully preserved ; in the universities, in the learned societies, in the various associations or institutions devoted to the advancement of knowledge. Whenever State support is given, a buffer should be interposed, similar to that provided by the University Grants Committee between the universities of Great Britain and the Treasury. In our existing Research Councils (Department of Scientific and Industrial Research, Medical Research Council, and Agricultural Research Council), working with Government funds, the buffer is already provided by the fact that the members of the Councils are chiefly independent scientific men. The same safeguard exists at present with much of our Stateaided research; we must earefully watch that the strength of this safeguard is fully maintained, that it does not become a formality, and that the principle is consciously extended wherever possible, as the financial burden of scientific research and development is taken over (as is bound to happen more and more) by the State.

In many of the departments of Government, however, notably those of the defence services, scientific research is undertaken, on a grand scale, which cannot be controlled directly by outside independent bodies. In these establishments particularly, the danger of stagnation and complacency exists. They are devoted to specific service purposes, often of necessity secret; and the condition of secrecy prevents them, in ordinary times, from attracting many of the ablest and brightest minds, who prefer the freer atmosphere of the universities, the possibility of discussing and publishing their results, and the recognition of their colleagues resulting therefrom. Consequently, in war, those who direct these establishments are often men who have arrived at their positions by seniority and long service, during which they have been largely isolated from the ideas and criticism of current scientific thought; it has been difficult for them not to become officials rather than working men of science. When an emergency occurs, as at present, numbers of able men come in, but to posts in which they can exert relatively little influence, and their ability and imagination may for long be imperfectly used. This indeed is inevitable under the present system, for they have at first no experience of service conditions and 
needs. After a year or two perhaps-longer than necessary-these able people find their proper level, but not until much damage has been done by lack of imagination and energy in the posts they might have filled before.

To avoid this trouble-and it is a very real onetwo main principles may be applied. First, to introduce into each department or organization some kind of scientific advisory council, similar to that which on the whole works so well now in the Ministry of Supply. This council should consist partly of independent scientific men chosen for their special knowledge on one hand, for their wide contact with the scientific community on the other; and partly of official scientific people representing not only the department or organization itself, but also a variety of other departments, so that a good cross-section of official knowledge and experience is available. Secondly, in ordinary times to arrange for regular interchange of personnel between the Government research establishments and organizations, and the universities and other independent institutions in which research is carried on.

I know that this second proposal will shock some of those who have lived in the traditional secrecy of service science; but it is right all the same. Why should not a chemist or mathematician from Woolwich, a physicist from the Signal School, an engineer from the Royal Aircraft Fistablishment, go back as a lecturer or professor to a university, or to the research staff in a commercial laboratory; just as a physiologist from the National Institute for Medical Research, or an aeronautical engineer at the National Physical Laboratory, or a zoologist at the Marine Biological Laboratory at Plymouth, may do ? And why should not the research workers in Government laboratories be just as regular attendants at the meetings of scientific societies as those in other institutions?

The first need is for a common pension scheme. All scientific workers, whether in the universities, or in commercial laboratories, or in Government employment, should come under the Federated Superannuation System for Universities, as do those employed by the Department of Scientific and Industrial Research, the Medical Research Council and the Agricultural Council. Then the Departments should insist on sending their people away at intervals, to carry on research elsewhere and to refresh their souls in institutions outside. Conversely, they should invite outside scientific workers (naturally under proper safeguards of secrecy when necessary) to work for corresponding periods in their establishments. The advantage of this second step would be that the importance and interest of the problems which are being tackled in Government establishments would be more commonly realized, and better men would be inclined to take part in their solution. In the defence services a reserve of officers and other ranks is an essential part of an efficient organization for war ; in the scientific services similarly, a reserve of research workers, for the case of emergency of any kind, would seem to be equally essential.

One great advantage of working in the scientific establishments either of the Government or of a large company or corporation, is the fact that equipment is not limited below the minimum that is necessary for efficiency. As regards research in the universities of Great Britain, I should feel inclined, if a Government fund of say one million pounds were available for scientific research, to ask the University Grants Committee to allocate it to different universities. Each university would then deal with the disposal of the sum allotted to it, in much the same way as the Royal Society does with the Government Grant for Scientific Investigation; and as in the last few years the University of London has already done with a substantial fund which it has put aside for this very purpose from its own resources. I know from long experience, both personally and by helping to administer the Royal Society grant, the great advantage to the individual and to the institution where he works, of the possibility of obtaining a grant, possibly large, more often small, for a specific research project; to be expended by the young research worker (or the older one) at his discretion and not merely by the department. What the University of London has made a start in doing in this way, can be done by other bodies; but money will be required. In the days of straitened circumstances which we cannot but foresee ahead, it must come from the State if scientific investigation is to be kept upas it must be ; and the natural body to allocate it to its different claimants among the universities would be the University Grants Committee.

For research in industry, in medicine and in agriculture (apart from their overlap with university institutions) the machinery for similar grants exists already in the three Research Councils; with extended financial provision from the Treasury if necessary. In industry, at least part of the sum required should be subscribed by the industry itself, as it is at present, with the research associations devoted to various subjects and working in co-operation with the Department of Scientific and Industrial Research. The personal grants given at present by the latter Department for researches "of particular timeliness and promise" are of great value and could with advantage be extended. 